\title{
IN SITU OBSERVATIONS OF FORAMINIFERAL BLEACHING IN THE MALDIVES, INDIAN OCEAN
}

\author{
Silvia Spezzaferri ${ }^{1,3}$, Akram El Kateb $^{1}{ }^{1}$ Chiara Pisapia $^{1}$ and Pamela Hallock ${ }^{2}$
}

\begin{abstract}
Coral reefs are threatened worldwide by a variety of natural and human-induced stressors; anomalous temperatures are presently among the most serious threats by causing extensive coral bleaching. Amphistegina spp. exhibit similar bleaching as corals in the presence of photo-oxidative stress induced by either light or temperature, especially during times of maximum solar irradiance. At 11 islands (34 sampling sites) in the North Ari Atoll in the Maldives, bleaching in Amphistegina was observed a few weeks before the onset of an extensive EI Niñorelated coral bleaching that was more severe than expected for this region. Assessment using the Amphistegina Bleaching Index (ABI) showed that the proportions of bleached specimens of Amphistegina in April-May 2015 can be explained by photoinhibitory stress associated with temperatures exceeding $30^{\circ} \mathrm{C}$ during peak seasonal solar irradiance and water transparency. Importantly, the ABI indicates that environmental conditions are suitable for Amphistegina and other calcifying symbioses at most of the investigated sites, and that either chronic or relatively recent onset of photo-oxidative stress was present at the time of sampling. The observed bleaching in Amphistegina further demonstrates the potential of these unicellular protists to identify stressors in coral reefs; such applications should be considered in future reef-management plans.
\end{abstract}

\section{INTRODUCTION}

Anomalously high temperatures can affect coral reefs worldwide, producing massive bleaching and consequently are among the primary threats to these ecosystems (e.g., Wilkinson et al., 1999; Graham et al., 2015). Climate-induced coral bleaching and subsequent loss of vital coral cover directly impact the economies of coastal regions dependent upon tourism and fisheries, as loss of coral directly compromises the related functions and services that coral reefs provide (Wilkinson et al., 1999).

The term "bleaching", in the context of organisms that host algal end osymbionts, is usually defined as the temporary or permanent loss of the symbiotic microalgae or the loss of their pigments (Glynn, 1996). Triggers of bleaching include, but are not limited to, high or low temperatures, salinity stress (Jokiel \& Coles, 1990), changes in visible or ultraviolet solar irradiance (e.g., Gleason \& Wellington, 1993; Glynn, 1996), sedimentation (Hoegh-Guldberg \& Smith, 1989), disease, pollution, heavy metals (Jones \& Hoegh-Guldberg, 1999), or a combination of these factors. Most reef-dwelling organisms that host algal symbionts are susceptible to bleaching includ-

\footnotetext{
${ }^{1}$ Department of Geosciences, Ch. Du Musée 6, Fribourg, 1700 Switzerland

2 College of Marine Science, University of South Florida, St. Petersburg, FL 33701 USA

${ }^{3}$ Correspondence author. E-mail: silvia.spezzaferri@unifr.ch
}

ing sponges, anemones, stony corals, octocorals, giant clams and larger foraminifers (e.g., Talge \& Hallock, 2003; Schmidt et al., 2011). The majority of coral-bleaching events have been associated with anomalous increases in sea-surface temperature (Jokiel \& Coles, 1990; Hoegh-Guldberg, 1999). Thermal and associated photo-inhibitory stresses are the main drivers of bleaching because thermal stress increases the susceptibility of the symbionts to photo-inhibition through photooxidative reactions, resulting in symbiont loss in corals and larger benthic foraminifers (Coles et al., 1976; Goreau \& Hayes; 1994; Glynn, 1996; Hoegh-Guldberg, 1999; Talge \& Hallock, 2003). In particular, when an excess of solar energy exceeds the rate of light utilization (photochemistry), production of reactive oxygen species (ROS) can damage both symbionts and the hosting cells (e.g., Lesser \& Farrell, 2004; Sheppard et al., 2009). During an acute bleaching episode, a coral host may lose up to $90 \%$ of its symbionts, while the remaining symbionts may lose $50-80 \%$ of their photosynthetic pigments (Glynn, 1996).

Larger benthic foraminifers $(\mathrm{LBF})$ are unicellular protists having symbiotic relationships with algae analogous to those in corals (Lee \& Anderson, 1991; Hallock, 1999). Bleaching in foraminifers was first described in laboratory experiments (Hallock et al., 1986), however, it was unknown in field populations until Hallock et al. (1993) collected several specimens of Amphistegina gibbosa that appeared "spotted" during a post-bleaching coral survey in 1988. Since 1991, some bleaching of $A$. gibbosa has been consistently observed in field samples from the Florida Keys during summer months (Hallock et al., 1995; Williams et al., 1997; Mendez-Ferrer et al., 2018). Symbiont loss may affect over $80 \%$ of the total adult Amphistegina population; individual specimens display unusual color sometimes restricted to a few white spots, or progressing to near absence of symbiont color (Hallock et al., 1995; Mendez-Ferrer et al., 2018). A detailed history of observations in foraminiferal bleaching in the Florida Keys is summarized in Hallock et al. (2006a). Since the first observations, bleaching in Amphistegina spp. has been documented on the eastern and western shelves of Australia, the Bahamas, Jamaica, Hawaii, and Micronesia (Hallock, 2000).

Based on many years of laboratory experiments and field observations, Hallock et al. (2006a, and references therein) summarized similarities and differences between bleaching in Amphistegina and bleaching in corals. They identified important differences in the modality, timing and causes of bleaching. In particular, they note that mass bleaching in corals occurs primarily by expulsion of symbionts; it requires high light intensity but most strongly correlates with elevated temperatures. In contrast, bleaching in Amphistegina occurs by digestion of damaged symbionts (Talge \& Hallock, 2003) and, in field studies, has been demonstrated to correlate with the solar cycle that precedes seasonal temperature extremes (Williams, 2002; Hallock et al., 2006a). 
Temperature can also induce bleaching in foraminifers (Talge \& Hallock, 2003; Schmidt et al., 2011; Stuhr et al., 2017). Schmidt et al. (2011) observed that a $2-3^{\circ} \mathrm{C}$ increase in temperature can produce rapid bleaching in several diatom-bearing benthic foraminiferal species, including Amphistegina, which hosts naked diatom cells lacking silica frustules (e.g., Lee \& Anderson, 1991; Talge \& Hallock, 2003). Laboratory experiments conducted by Schmidt et al. $(2016 \mathrm{a}, \mathrm{b})$ demonstrated that reduced photosynthetic activity in Amphistegina lobifera occurs at $32^{\circ} \mathrm{C}$. The combination of elevated temperatures, nutrients and bleaching in A. lobifera from outer-shelf habitats on the Great Barrier Reef, Australia, has been reported by Prazeres et al. (2016, 2017).

Biotic indices are quantitative indicators for ecological water quality based on faunal composition in sediments (e.g., Borja et al., 2011; Alve et al., 2016). Bioindicator species can be used as a measure or a model to characterize an ecosystem or one of its critical components (Jackson et al., 2000). A biotic index, based on abundance and population health state of the bioindicator Amphistegina spp., was proposed by Hallock (1995), discussed further by Hallock et al. (2006b), and improved by Ramirez (2008). However, this index has not been tested further outside Florida.

Maldivian coral reefs are some of the most diverse reefs of the Indian Ocean, hosting more than 250 species of corals and 1200 species of fish (Naseer \& Hatcher, 2004). Their remote location, combined with a fishery that historically has not been based on reef fish, place them among the reefs across the world with relatively low local anthropogenic disturbances. Despite their isolation, Maldivian reefs have been severely affected by coral bleaching with many reefs losing more than $80 \%$ of their coral cover following the 1998 bleaching event (McClanahan, 2000; Morri et al., 2015). Post bleaching recoveries have been variable with respect to rates of recovery of coral cover and return to the original community composition (McClanahan, 2000; Edwards et al., 2001; Morri et al. 2015)

The goals of our study were to quantify occurrences of bleached specimens of Amphistegina spp. collected from coral reefs near 11 Maldivian islands in the North Ari Atoll (Fig. 1), during the REGENERATE Cruise in 2015. Importantly, this study also aimed to apply the index proposed for the reefs in Florida by Hallock et al. (2006b) and applied by Ramirez (2008; hereafter termed Amphistegina Bleaching Index, ABI) and to test whether the visual response to stressors of Amphistegina populations has the potential to serve as a low-cost risk-assessment tool for the Maldivian reefs in view of climate change or local anthropogenic impacts. The ABI was not conceived as an indicator of coral bleaching per se but, if combined with ecological data and physical parameters, can be used to determine the presence of stressors that could induce coral bleaching. The ABI indicates whether water quality supports calcifying symbioses and whether damaging photo-inhibitory stress is present in the environment (Hallock et al., 2006b). This research is the first to provide an ABI data set for the Maldivian coral reefs, and, in addition to data from Florida (summarized in Hallock et al., 2006a), it provides the framework for future application of the ABI to reefs worldwide in the context of climate change.

\section{MATERIALS AND METHODS}

The Maldives include 16 complex atolls with $>1100$ islands extending from the central part of the Chagos-MaldivesLaccadive ridge in the central Indian Ocean, from approximately $7^{\circ} 07^{\prime} \mathrm{N}$ to $0^{\circ} 40^{\prime} \mathrm{S}$ in latitude and $72^{\circ} 33^{\prime} \mathrm{E}$ to $73^{\circ} 45^{\prime} \mathrm{E}$ in longitude. Eleven islands were surveyed between 22 April-6 May 2015 (Fig. 1) during the International Union for Conservation of Nature (IUCN) REGENERATE Cruise. Surveyed islands included three community islands: Rasdhoo, Feridhoo and Maalhos; four uninhabited islands: Gaathafushi, Alikoirah, Vihamafaru and Madivaru; and four resort islands: Velidhu, Kandholhudhoo, Maayafushi, and Madoogali. At each island reef, three sites at $10 \mathrm{~m}$ water depth were randomly chosen along the slope, and nine pieces of coral rubble per sampling sub-site (27 per island) were collected by SCUBA divers to quantify bleaching in Amphistegina spp. The positions of each site and sub-site are shown in detail in Pisapia et al. (2016). Each count of living Amphistegina was based on nine pieces of reef rubble for each sampling site (a, $\mathrm{b}$ and $\mathrm{c}$ in Table 1). On the vessel, rubble samples were stored in Petri dishes in the shade for a maximum of two hours before processing. Although strict control of temperature and light was not logistically practical, exposure to bright light and temperature extremes $\left(\right.$ e.g., $>3^{\circ} \mathrm{C}$ ) were avoided, as recommended by Hallock et al. (2006b).

To evaluate the number of bleached Amphistegina, biogenic material was removed from the rubble surfaces using a small brush and the resultant sediment-meiobenthos slurries were placed in labeled Petri dishes. Rubble pieces were also scrutinized using a stereomicroscope to record stillattached specimens. Material scrubbed from rubble was left to rest for a few hours and then all specimens belonging to the genus Amphistegina showing pseudopodial activity (e.g., when pseudopods were visibly extruded from the test and/or the specimens displayed ability to move) were picked using a small brush, counted and evaluated for the degree of bleaching following Hallock et al. (2006a, b) and Ramirez (2008). The categories evaluated were: Normal $=$ no bleaching observed; partially bleached $=<50 \%$ of bleached surface; completely bleached $=>50 \%$ of bleached surface. Each piece of rubble was photographed on a gridded paper to estimate area of bottom cover. All images were then processed using the software Image J (http://imagej.nih.gov/ij) to quantify the planar areal extent of every rubble piece.

Basic data from each site were a) bottom area of the rubble in $\mathrm{cm}^{2}, \mathrm{~b}$ ) total number of live Amphistegina (adults and juveniles), and c) numbers of normal-appearing, partially, and completely bleached specimens. The Amphistegina Bleaching Index was calculated following Ramirez (2008) based on the density of Amphistegina and the percent experiencing bleaching (Table 1), to assess whether water quality supports calcifying symbioses and whether damaging photo-inhibitory stress is present in the environment. On the $\mathrm{X}$-axis of the matrix (Fig. 2A, B), the density rank was plotted, which represents the number of live Amphistegina standardized for a rubble area of $100 \mathrm{~cm}^{2}$ (number of live Amphistegina/rubble area in $\left.\mathrm{cm}^{2}\right)$ in three categories $\left(<10^{1} / 100 \mathrm{~cm}^{2}, 10^{1}-10^{2} / 100\right.$ $\left.\mathrm{cm}^{2},>10^{2} / 100 \mathrm{~cm}^{2}\right)$. On the Y-axis, the bleaching rank was plotted, which represents the relative abundance of bleached specimens in three categories $(>40 \%, 5-40 \%$ and $<5 \%)$. The 
TABLE 1. Average abundances per site of partially bleached, completely bleached and total specimens exhibiting bleaching Amphistegina spp., plotted versus their abundance per $100 \mathrm{~cm}^{2}$ of rubble surface. $\mathrm{PB}=$ Partially bleached; $\mathrm{CB}=$ Completely bleached; a, $\mathrm{b}$ and $\mathrm{c}$ mark the sub-sampling sites.

\begin{tabular}{|c|c|c|c|c|c|c|c|c|c|c|c|}
\hline Island & Site & Total Living & Normal Spec. & PB Spec. & CB Spec. & TB Spec. & Rubble Area & Living $\mathrm{x} 100 \mathrm{~cm}^{2}$ & $\% \mathrm{~PB}$ & $\% \mathrm{CB}$ & $\% \mathrm{~TB}$ \\
\hline \multirow[t]{3}{*}{ Rasdhoo (c) } & $\mathrm{a}$ & 225 & 134 & 82 & 9 & 91 & 93.6 & 240 & 36.4 & 4 & 40.4 \\
\hline & $\mathrm{b}$ & 202 & 134 & 66 & 2 & 68 & 86.7 & 233 & 32.7 & 0.99 & 33.7 \\
\hline & $\mathrm{c}$ & 73 & 58 & 11 & 4 & 15 & 120 & 60.7 & 15.1 & 5.48 & 20.6 \\
\hline \multirow[t]{2}{*}{ Feridhoo (c) } & $\mathrm{a}$ & 9 & 8 & 1 & 0 & 1 & 93.5 & 9.63 & 11.1 & 0 & 11.1 \\
\hline & $\mathrm{c}$ & 5 & 5 & 0 & 0 & 0 & 104 & 4.79 & 0 & 0 & 0 \\
\hline \multirow[t]{2}{*}{ Maalhos (c) } & $\mathrm{a}$ & 46 & 28 & 15 & 3 & 18 & 49.5 & 92.9 & 32.6 & 6.52 & 39.1 \\
\hline & $\mathrm{b}$ & 14 & 10 & 4 & 0 & 4 & 80.8 & 17.3 & 28.6 & 0 & 28.6 \\
\hline \multirow[t]{3}{*}{ Alikoirah (u) } & $\mathrm{a}$ & 8 & 5 & 3 & 0 & 3 & 73.9 & 10.8 & 37.5 & 0 & 37.5 \\
\hline & $\mathrm{b}$ & 47 & 31 & 11 & 3 & 14 & 87.0 & 54.0 & 23.4 & 6.38 & 29.8 \\
\hline & $\mathrm{c}$ & 58 & 48 & 10 & 0 & 10 & 71.6 & 81.0 & 17.2 & 0 & 17.2 \\
\hline \multirow[t]{5}{*}{ Vihamafaru (u) } & $\mathrm{a}$ & 71 & 64 & 7 & 0 & 7 & 90.9 & 78.1 & 9.86 & 0 & 9.86 \\
\hline & $\mathrm{b}$ & 117 & 96 & 21 & 0 & 21 & 111 & 105 & 17.9 & 0 & 17.9 \\
\hline & $\mathrm{c}$ & 27 & 18 & 9 & 0 & 9 & 89.7 & 30.1 & 33.3 & 0 & 33.3 \\
\hline & $a b$ & 84 & 69 & 12 & 3 & 15 & 80.5 & 104 & 14.3 & 3.57 & 17.9 \\
\hline & $\mathrm{bb}$ & 97 & 60 & 18 & 19 & 37 & 70.6 & 137 & 18.6 & 19.59 & 38.1 \\
\hline & $\mathrm{c}$ & 50 & 45 & 4 & 1 & 5 & 74.3 & 67.2 & 8.0 & 2.0 & 10.0 \\
\hline \multirow[t]{3}{*}{ Gaathafushi (u) } & $\mathrm{a}$ & 61 & 52 & 6 & 0 & 6 & 73.1 & 83.5 & 9.84 & 0 & 9.84 \\
\hline & $\mathrm{b}$ & 43 & 33 & 10 & 0 & 10 & 73.6 & 58.4 & 23.3 & 0 & 23.3 \\
\hline & $\mathrm{c}$ & 24 & 20 & 4 & 0 & 4 & 78.3 & 30.7 & 16.7 & 0 & 16.7 \\
\hline \multirow[t]{3}{*}{ Velidhu (u) } & $\mathrm{a}$ & 50 & 34 & 8 & 8 & 16 & 52 & 96.2 & 16.0 & 16.0 & 32.0 \\
\hline & $\mathrm{b}$ & 14 & 7 & 7 & 0 & 7 & 30.6 & 546 & 50.0 & 0 & 50.0 \\
\hline & $\mathrm{c}$ & 35 & 2 & 9 & 24 & 33 & 34.8 & 101 & 25.7 & 68.57 & 94.3 \\
\hline \multirow[t]{3}{*}{ Maayafushi (r) } & $\mathrm{a}$ & 113 & 105 & 15 & 13 & 28 & 82.0 & 162 & 11.3 & 9.77 & 21.1 \\
\hline & $\mathrm{b}$ & 157 & 138 & 11 & 8 & 19 & 77.6 & 202 & 7.01 & 5.10 & 12.1 \\
\hline & $\mathrm{c}$ & 60 & 49 & 11 & 0 & 11 & 74.9 & 80.1 & 18.3 & 0 & 18.3 \\
\hline \multirow[t]{3}{*}{ Madoogali (r) } & $\mathrm{a}$ & 27 & 11 & 11 & 5 & 16 & 57.3 & 47.1 & 40.7 & 18.52 & 59.3 \\
\hline & $b$ & 45 & 36 & 7 & 2 & 9 & 64.0 & 70.3 & 15.6 & 4.44 & 20.0 \\
\hline & $\mathrm{c}$ & 33 & 26 & 7 & 0 & 7 & 67.5 & 48.9 & 21.2 & 0 & 21.2 \\
\hline \multirow[t]{3}{*}{ Kandholhudhoo (r) } & $\mathrm{a}$ & 23 & 17 & 6 & 0 & 6 & 82.1 & 28.0 & 26.1 & 0 & 26.1 \\
\hline & $\mathrm{b}$ & 70 & 55 & 11 & 4 & 15 & 79.0 & 88.6 & 15.7 & 5.71 & 21.4 \\
\hline & $\mathrm{c}$ & 58 & 33 & 21 & 4 & 25 & 84.4 & 68.7 & 36.2 & 6.90 & 43.1 \\
\hline
\end{tabular}

intercept point of these two parameters on the matrix (Fig. 2A, B) represents the Amphistegina Bleaching Index, which may fall in one of the nine squared fields describing an ecological status.

Water samples, which were collected into plastic bottles by SCUBA divers, were taken above the seabed from the same locations where coral rubble samples were collected. Immediately after collection of water samples, $\mathrm{pH}$, temperature and conductivity were measured using a multiparameter meter Orion $^{\mathrm{tm}}$ Star A325. Dissolved oxygen (DO) was measured with DO600 Waterproof ExStik ${ }^{\circledR}$ II Dissolved Oxygen Meter, which has an auto-calibration function. Full details of conductivity to salinity calculations, model sensors and calibrations are described in Pisapia et al. (2016). Water parameters were also measured at the sea surface to record potential difference between the surface and the sea floor (10 $\mathrm{m}$ depth). In some cases conditions, such as rough sea prevented the collection of water samples (e.g., Madivaru).

\section{RESULTS}

Live Amphistegina were recorded at all sites (Fig. 1, Table $1)$, though $<20$ specimens were found at 5 of the 34 sites $(15 \%)$; when corrected for area sampled, $<50$ specimens/100 $\mathrm{cm}^{2}$ were recorded at 10 sites $(30 \%)$. At 23 sites (with $\geq 20$ live specimens; $79 \%$ of total investigated sites), between 10
41\% of the Amphistegina specimens were partially bleached (Table 1). When bleached specimens are added to the totals, $>6 \%$ of the specimens exhibited symbiont loss at all of the 29 sites and $>10 \%$ at 25 of the 29 sites (Table 1). The percentage of live specimens exhibiting partial or complete bleaching exceeded $60 \%$ at only one site (Table 1 ).

The application of the ABI, based on the table matrix proposed by Ramirez (2008), and based on the percent bleached specimens (partially + completely bleached) as summarized in Figure 2A, B, revealed that most sites fell in fields BB (chronic photo-inhibitory stress, possibly other stressors) and BA (stress either chronic and mild or recent and moderate). Five samples all from sites near inhabited or resort islands fell within the CB field (acute photo-inhibitory stress or chronic photo-inhibitory stress with other stressors). Samples from one community island had very low density (AC or $\mathrm{BC}$, environmental conditions unfavorable), while one higher density sample showed $>40 \%$ exhibiting bleaching, likely indicating recent, acute photo-oxidative stress (Fig. 2B).

Mean values of temperature $\left({ }^{\circ} \mathrm{C}\right)$, DO $\left(\mathrm{mg} \mathrm{L}^{-1}\right)$, conductivity $(\mathrm{mS} / \mathrm{cm})$, salinity $\left(\%_{0}\right)$ and $\mathrm{pH}$ are presented in Table 2. Mean temperatures ranged from $28.8-31.8^{\circ} \mathrm{C}$, with the overall mean at $10 \mathrm{~m}$ depth of $30.3^{\circ} \mathrm{C}$. During the cruise, a generalized warming occurred in the region and, as a result, the highest temperatures (up to $32.2^{\circ} \mathrm{C}$, see Pisapia et al., 2016) were recorded at the resort island of Kandholhudhoo on 


\begin{tabular}{|c|c|c|c|}
\hline $\begin{array}{c}\mathrm{A} \\
<5 \%\end{array}$ & $\begin{array}{l}\text { Environmental } \\
\text { conditions } \\
\text { unfavorable } \\
\text { AC }\end{array}$ & $\begin{array}{c}\text { Chronic } \\
\text { non-photo-inhibitory stress } \\
\mathrm{AB}\end{array}$ & $\begin{array}{l}\text { Environmental } \\
\text { conditions } \\
\text { near optimal } \\
\text { AA }\end{array}$ \\
\hline 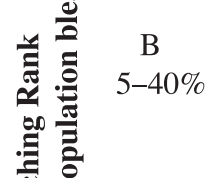 & $\begin{array}{c}\text { Chronic photo-inhibitory } \\
\text { stress, } \\
\text { other stressors } \\
\text { BC }\end{array}$ & $\begin{array}{l}\text { Chronic photo-inhibitory } \\
\text { stress, } \\
\text { possibly other stressors } \\
\text { BB }\end{array}$ & $\begin{array}{l}\text { Photo-inhibitory stress } \\
\text { eitherchronic and mild or } \\
\text { recent and moderate } \\
\text { BA }\end{array}$ \\
\hline $\begin{array}{cc}\text { b } & C \\
\text { ê } & >40 \%\end{array}$ & $\begin{array}{c}\text { Ongoing acute } \\
\text { photo-inhibitory } \\
\text { stress, other stressors } \\
\text { CC }\end{array}$ & $\begin{array}{l}\text { Acute photo-inhibitory stress, } \\
\text { possibly other stressors } \\
\text { CB }\end{array}$ & $\begin{array}{l}\text { Recent on set of acute } \\
\text { photo-inhibitory stress } \\
\text { CA }\end{array}$ \\
\hline
\end{tabular}

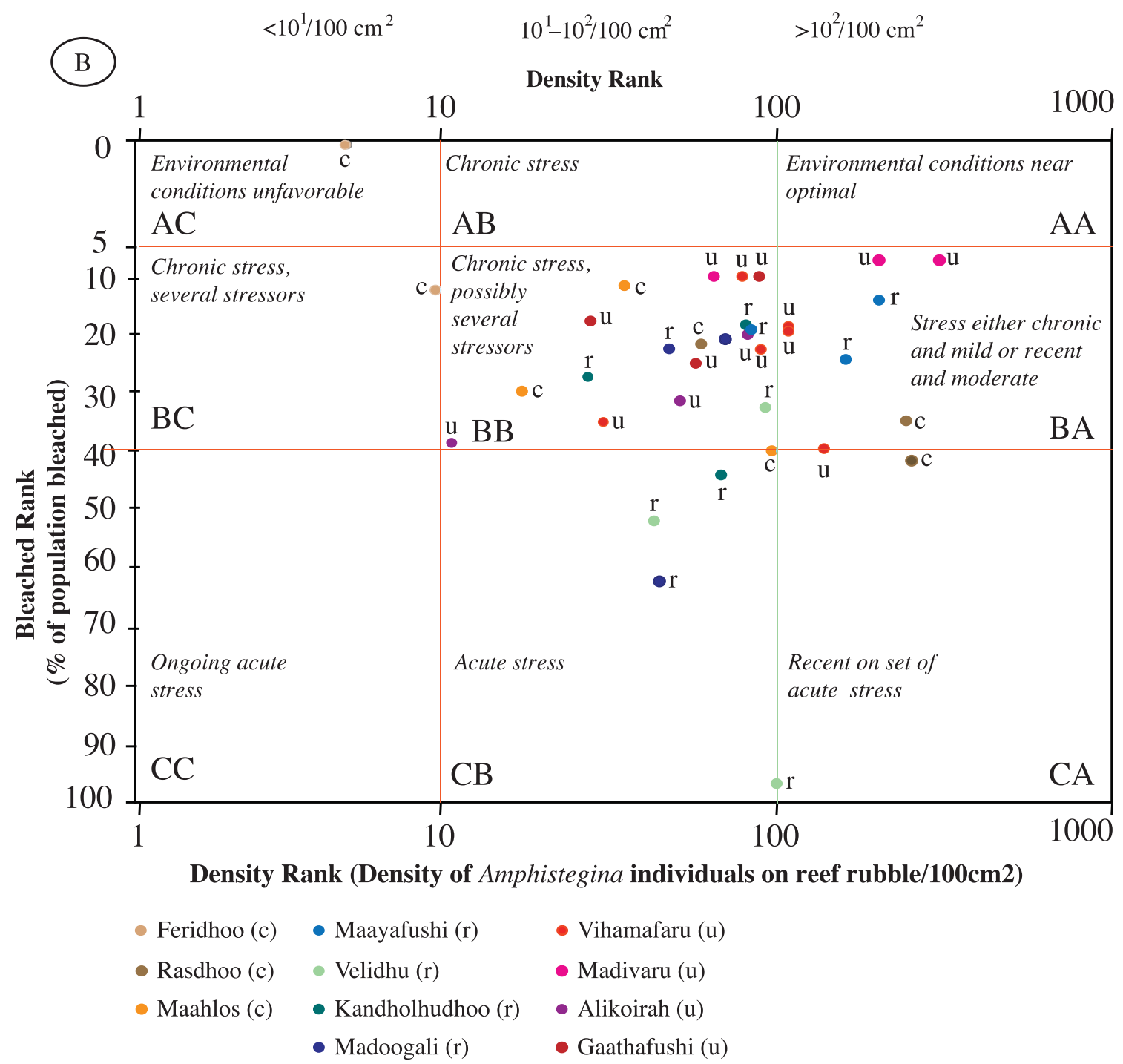

Figure 2. (A) Matrix modified from Ramirez (2008) used for the Amphistegina Photic Index, based on the density of Amphistegina and the percent of Amphistegina specimens experiencing bleaching in a sample (re-drawn after Ramirez, 2008). High densities of live, healthy Amphistegina $\left(>50 / 100 \mathrm{~cm}^{2}\right)$ on rubble in reefal habitats indicates that ambient water quality supports this and other calcifying host-symbiont associations. Low densities, in which most samples indicate densities $\left(<10 / 100 \mathrm{~cm}^{2}\right)$ indicate that conditions do not support calcifying host-symbiont associations, with moderate densities (10-50/100 $\mathrm{cm}^{2}$ ) indicating marginal conditions. (B) The Amphistegina Bleaching Index (ABI) in the North Ari Atoll, based on the density of Amphistegina and the percent of Amphistegina specimens experiencing bleaching (modified after Ramirez, 2008). On the X-axis, the density rank (Amphistegina spp. per $100 \mathrm{~cm}^{2}$ expressed in $\log _{10}$ ); on the Y-axis is the bleached rank: \% of total (partially bleached + completely bleached population). The sites are named with $\mathrm{u}$ (uninhabited islands), $\mathrm{c}$ (community islands) and $\mathrm{r}$ (resort islands) to distinguish the three categories. The full name of each site is presented in the legend. 
TABLE 2. Mean values for water sample parameters measured at each site and group of sites. (Modified after Pisapia et al., 2016).

\begin{tabular}{|c|c|c|c|c|c|c|}
\hline Site & Depth (m) & $\mathrm{pH}$ & $\mathrm{T}\left({ }^{\circ} \mathrm{C}\right)$ & Cond. $(\mathrm{ms} / \mathrm{cm})$ & $\mathrm{DO}\left(\mathrm{mg} \cdot \mathrm{L}^{-1}\right)$ & Salinity $(\% 0)$ \\
\hline Rasdhoo & 10 & 8.18 & 30.08 & 51.96 & 5.35 & 34.31 \\
\hline Feridhoo & 10 & 8.04 & 30.30 & 51.61 & 5.94 & 33.92 \\
\hline Maalhoss & 10 & 8.01 & 30.71 & 51.56 & 6.12 & 33.88 \\
\hline Community Mean & 10 & 8.07 & 30.36 & 51.71 & 5.80 & 34.04 \\
\hline Community & Surface & 8.14 & 30.59 & 51.72 & 7.99 & 34.11 \\
\hline Velidhoo & 10 & 8.15 & 28.89 & 51.79 & 5.65 & 34.06 \\
\hline Madoogali & 10 & ND & 30.02 & 51.81 & 4.80 & 34.07 \\
\hline Kandholhudhoo & 10 & 8.03 & 31.76 & 50.50 & 6.13 & 33.11 \\
\hline Resort Mean & 10 & 8.08 & 30.39 & 53.15 & 5.42 & 35.08 \\
\hline Resort & Surface & 8.16 & 30.59 & 58.17 & 8.27 & 35.09 \\
\hline Vihamaafaru & 10 & 8.05 & 30.15 & 51.21 & 5.55 & 33.63 \\
\hline Gaathafushi & 10 & 8.04 & 30.97 & 51.75 & 5.63 & 34.03 \\
\hline Alikoirah & 10 & 8.04 & 30 & 50.52 & 5.24 & 33.14 \\
\hline Uninhabited Mean & 10 & 8.04 & 30.37 & 51.16 & 5.47 & 33.60 \\
\hline Uninhabited & Surface & 8.16 & 30.70 & 51.11 & 8.43 & 33.56 \\
\hline
\end{tabular}

29 April 2015 (Fig. 3). Dissolved oxygen varied from 4.8-6.1 $\mathrm{mg} \mathrm{L}^{-1}$ at $10 \mathrm{~m}$ depth, and was $\geq 8 \mathrm{mg} \mathrm{L}^{-1}$ in surface-water samples. The $\mathrm{pH}$ varied from 8.0 to 8.2 . Salinity ranged from 33.0-35.1, with minimal variability across all sites, except for Maayafushi, where the anomalously high salinity values (up to 39 ) were probably due to instrumental problems.

\section{DISCUSSION}

Foraminifers are well-established indicators of water quality based on cellular responses (e.g., Murray, 2006; Prazeres et al., 2011, 2012) to morphological and community composition (Hallock, 2012; Reymond et al., 2012). Combining foraminiferal studies with ecological data and physical parameters may be helpful to describe environmental conditions that can induce bleaching. Amphistegina is a circumtropically-distributed genus of benthic foraminifers (e.g., Langer et al., 2013) that thrives in high water quality (e.g., low inorganic nutrients, low sedimentation and low turbidity). Talge \& Hallock (2003) demonstrated that the cytological responses to bleaching of field-collected Amphistegina and specimens from laboratory cultures were statistically indistinguishable, indicating the potential for this genus to be used as a tool to investigate the presence of photo-oxidative stresses that could lead to coral bleaching.

Temperature, $\mathrm{DO}$ and $\mathrm{pH}$ are highly dependent upon time of day of measurement, while both temperature and salinity can be influenced by tidal cycle and local conditions such as rainfall or evaporation in shallow reef flat in hot, dry weather (Yates et al., 2007; Wild et al., 2010). The range of $\mathrm{pH}(8.0-$ $8.2)$ is typical of tropical waters during the warm, dry season (Table 2). The range of DO $\left(4.8-8.4 \mathrm{mg} \mathrm{L}^{-1}\right)$ is typical of the diurnal cycle in well-oxygenated waters, where lower morning DO is reduced by the influence of nighttime respiration, and higher afternoon DO reflects the accumulated influence of photosynthesis over the course of the day (Yates et al., 2007; Wild et al., 2010). All measured water parameters were within the typical ranges in the Indian Ocean, tropical settings and/or coral reef environments (Ramamirtham, 1968; Wild et al., 2010; Zweng et al., 2013; Lauvset et al., 2015) and should not have stressed the Amphistegina populations. Additionally, Pisapia et al. (2016) demonstrated that the management regime (community, resort and uninhabited islands) does not remarkably influence the measured water parameters and that benthic foraminiferal assemblages are typical of tropical reefs in the North Ari Atoll, with minimal

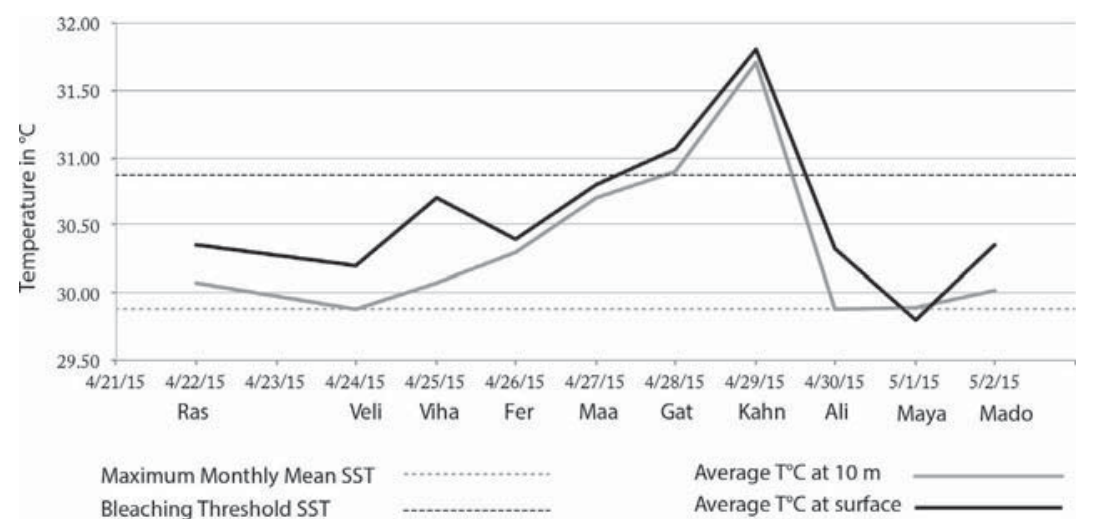

FIGURE 3. Average temperatures measured in selected islands from the North Ari Atoll showing the increasing temperature during the REGENERATE Cruise. 


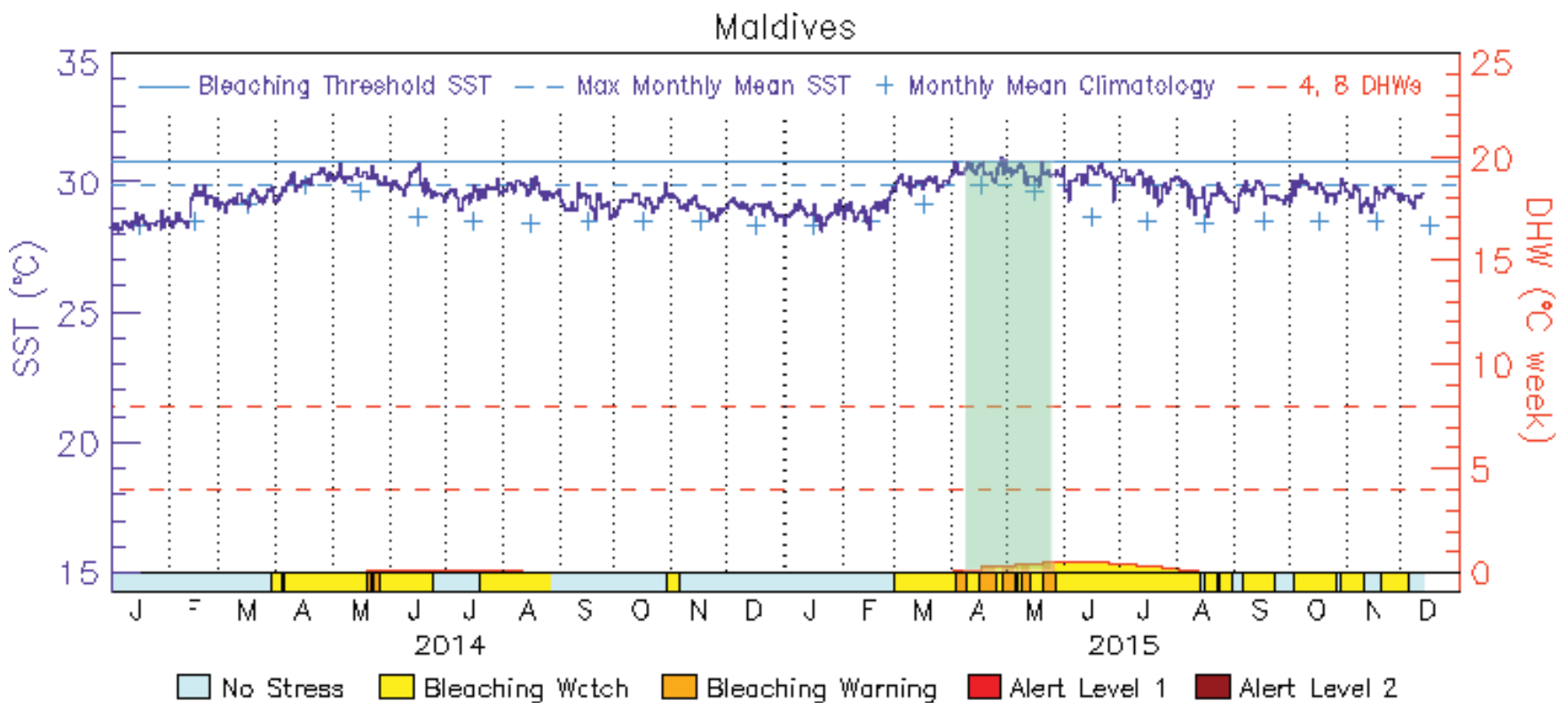

FIgURE 4. Summary of thermal conditions at the Maldives in 2014 and 2015. Modified after NOAA Coral Reef Watch (2015a). The period of the REGENERATE Cruise is marked with a green vertical bar. DHW = Degree Heating Week; SST = Sea Surface Temperature.

differences among sites. The only parameter assessed at the sampling sites that appears problematic is temperature (means range between $28.8-31.7^{\circ} \mathrm{C}$ ), with only two of the means reported in Table 2 falling below $30^{\circ} \mathrm{C}$, and several exceeding $30.5^{\circ} \mathrm{C}$. Schmidt et al. (2011) have shown that temperature effects are species-specific, and that a temperature above $31^{\circ} \mathrm{C}$ has a negative effect on Amphistegina. Several authors have demonstrated that temperatures exceeding $30^{\circ} \mathrm{C}$ significantly decrease photosynthetic activity in the diatom symbionts of LBF (Sinutok et al., 2011; Uthicke et al., 2012; Schmidt et al., 2016a, b; Stuhr et al., 2017).

Amphistegina spp. generally colonize hard and phytal substrates from shallow depths down to around $120 \mathrm{~m}$, depending upon the penetration limits of visible radiation (Hallock, 1999; Hohenegger et al., 1999). Healthy Amphistegina are known to be negatively phototactic at light intensities only slightly above those supporting optimal growth rates (Lee \& Anderson, 1991), therefore, they move to avoid photoinhibitory stress. However, as noted in previous bleaching studies (Hallock et al., 1995), photo-oxidative damage in Amphistegina disrupts normal phototaxis, such that stressed specimens tend to seek light rather than retreat.

Amphistegina bleaches when exposed to photo-oxidative stress, whether the stress is primarily induced by light or by temperature. Hallock et al. (1995) demonstrated that onset of bleaching in Amphistegina consistently preceded maximum temperatures (see also Mendez-Ferrer et al., 2018). The response to acute photo-inhibition occurs within hours to days and to chronic stress over several days to a few weeks (Hallock et al., 1995, 2006a; Stuhr et al., 2017). These responses can be detected cytologically before visible loss of symbionts becomes evident (Talge \& Hallock, 1995, 2003). In contrast, the overall reaction of a coral ecosystem may occur weeks, even months, after initiation of the stress event.

In this study, the observed bleaching in Amphistegina in late April and early May 2015 occurred during the highest temperatures and highest bleaching warning (Figs. 3, 4), as documented by NOAA Coral Reef Watch (2015a). Although neither solar irradiance nor photo-oxidative stress were directly assessed at the sites examined in this study, our fieldwork occurred soon after the sun was directly overhead at the $\sim 4^{\circ} \mathrm{N}$ latitude sites sampled, at the end of the dry season, together indicating maximum solar irradiance reaching the seafloor at $10 \mathrm{~m}$. April and May also are typically the hottest months (Fig. 4) which, combined with maximum solar irradiance, can result in the highest potential for photo-inhibitory stress. Thus, while this study did not definitely demonstrate that temperature was the predominant stressor at our study sites and did not explicitly test photo-oxidative stress, other potential sources of "stress" (salinity, $\mathrm{pH}$, and DO, and management regime in the North Ari Atoll) assessed in this study all occurred within normal ranges for tropical waters and can be excluded. In particular, ABI values for resort, inhabited and community islands generally fall within the same fields of either chronic or recent onset of moderate stress (Fig. 2B) indicating that the management regime did not play a role in Amphistegina bleaching.

When a suite of samples are collected, Amphistegina densities in the absence of bleaching can reflect water quality (Hallock et al., 2003; Hallock, 2012). Thus, Amphistegina densities combined with bleaching prevalence together can indicate kinds, duration and intensity of stress (Hallock et al., 2006b). Specifically, low Amphistegina densities with lowintermediate bleaching percentages indicate unfavorable water quality, while low densities and high (acute) bleaching percentages in adult size-classes can indicate ongoing acute photo-oxidative stress. Intermediate-high densities with high bleaching percentages indicate favorable water quality and relatively recent acute photo-oxidative stress, while intermediate densities and intermediate bleaching percentages indicate chronic stressors, one of which is photo-inhibitory stress (Hallock et al., 2006b). The density data presented in 
Figure 2, and the water quality data in Table 2, indicated that DO, $\mathrm{pH}$ and salinity conditions were suitable for Amphistegina and other calcifying symbioses at the sites sampled in North Ari Atoll. However, the incidences of partial to severe bleaching indicated either chronic or relatively recent onset of moderate stress. This observation corroborates the environmental assessment based on total benthic foraminiferal assemblages of Pisapia et al. (2016). This study used the Maldivian system as a novel example to test the ABI, and documented that $\mathrm{ABI}$ can be successfully used to assess relative degree of stresses including bleaching. Sampling methods for $\mathrm{ABI}$ are not destructive, only require collection of coral rubble, counts of living Amphistegina and degree of bleaching (absent, chronic, or acute), and therefore can easily be incorporated into a preexisting monitoring program (Hallock et al., 2006b) based on coral investigations.

Hoegh-Guldberg (1999) and Wilkinson (1999) linked sustained periods characterized by higher temperatures (a few degrees above the local average maximum) to coral mass bleaching. Strong et al. (1998) and Hoegh-Guldberg (1999) showed that only one degree above normal temperature lasting for one month may be responsible for bleaching in the majority of susceptible corals in an ecosystem. More recently, Frieler et al. (2013) concluded that limiting low-latitude warming to $<1.5^{\circ} \mathrm{C}$ will be necessary to preserve coral reefs worldwide. The threshold for coral bleaching in the Maldives, given by NOAA as just below $31^{\circ} \mathrm{C}$, was reached during April and May 2015, and lasted for at least 2 months (Fig. 4).

The major mass-bleaching events in the past two decades have occurred during ENSO years (Hoegh-Guldberg, 1999), and particularly the global bleaching events in 1998 (e.g., Hoegh-Guldberg, 1999; Wilkinson, 1999; Kelmo \& Attrill, 2013) and 2010 (e.g., Miranda et al., 2013). Temperature anomalies ranged from $3-5^{\circ} \mathrm{C}$ higher with respect to the normal annual average in 1998 (Wilkinson, 1999), but they were less extreme in 2010. A coral bleaching event occurred in June 2015 in the North Ari Atoll, triggered by El Niñoassociated anomalous temperatures, affecting several coral taxa, in particular Pocillopora (CP, personal observation). Based on local observations, coral bleaching in the Maldives was variable but more severe than expected from the level of thermal stress (NOAA Coral Reef Watch, 2015b). The moderate photo-inhibitory stress, as shown by Amphistegina in April-May 2015, occurred when solar irradiance and water transparency were highest, indicating elevated photo-oxidative stresses predating the extreme thermal El Niño pulse heralding a mass bleaching event.

\section{CONCLUSION}

Bleaching in Amphistegina spp. was observed at 11 islands in the North Ari Atoll in the Maldives during the REGENERATE Cruise in April-May 2015. The Amphistegina Bleaching Index (ABI) proposed by Hallock et al. (2006b) indicated that the proportions of bleached specimens of Amphistegina in April-May 2015 at these sites were likely associated with photo-inhibitory stress induced by seawater temperatures exceeding $30^{\circ} \mathrm{C}$ during peak seasonal solar irradiance. The $\mathrm{ABI}$ indicated that environmental conditions in the North Ari Atoll were suitable for calcifying symbioses at most of the investigated sites, with chronic or relatively recent onset of moderate stress at some sites (as indicated by observations of 5-40\% specimens with bleaching), which likely reflected El Niño conditions. This study further demonstrated how these unicellular protists respond to stressors in reef environments and their potential to predict coral bleaching.

\section{ACKNOWLEDGMENTS}

This study stems from a joint scientific expedition IUCN/Marine Research Centre (MRC) /University of Queensland, to study coral reef health and resilience in North Ari Atoll in the Maldives. We thank the IUCN for inviting three authors (SS, AEK, CP) to participate in the expedition, which was fully funded by the United States Agency for International Development. We warmly thank the Ministry of Environment and Energy, the MRC. Thanks to the crew of the Theia liveaboard for logistical assistance. The specific permission to collect the studied samples was granted by the Maldivian Marine Research Center, Ministry of Fisheries and Agricolture, permit N. (OTHR)30-D/INDIV/2015/165. We acknowledge the Swiss National Science Foundation Projects 200021_149589 and IZK0Z2_165131 for supporting shore-based investigations. Rubble pieces were left in Male in the IUCN Office after the expedition. Dr. Claire Reymond kindly served as JFR Guest Editor for this manuscript.

\section{REFERENCES}

Alve, E., Korsun, S., Schönfeld, J., Dijkstra, N., Golikova, E., Hess, S., Husum, K., and Panieri, G., 2016, Foram-AMBI: A sensitivity index based on benthic foraminiferal faunas from North-East Atlantic and Arctic fjords, continental shelves and slopes: Marine Micropaleontology, v. 122, p. 1-12.

Borja, A., Barbone, E., Basset, A., Borgersen, G., Brkljacic, M., Elliott, M., Mikel Garmendia, J., Marques, J. C., Mazik, K., Muxika, I., Magalhaes Neto, J., Norling, K., German Rodriguez, J., Rosati, I., Rygg, B., Teixeira, H., and Trayanova, A., 2011, Response of single benthic metrics and multi-metric methods to anthropogenic pressure gradients, in five distinct European coastal and transitional ecosystems: Marine Pollution Bulletin, v. 62, p. 499-513.

Coles, S. L., Jokiel, P. L., and Lewis, C., 1976, Thermal tolerance in tropical versus subtropical Pacific reef corals: Pacific Science, v. 30, p. $159-166$.

Edwards, A. J., Clark, S., Zahir, H., Rajasuryia, A., Naseer, A., and Rubens, J., 2001, Coral bleaching and mortality on artificial and natural reefs in Maldives in 1998, sea surface temperature anomalies and initial recovery: Marine Pollution Bulletin, v. 42, p. 7-15.

Frieler, K., Meinshausen, M., Golly, A., Mengel, M., Lebek, K., Donner, S. D., and Hoegh-Guldberg, O., 2013, Limiting global warming to $2{ }^{\circ} \mathrm{C}$ is unlikely to save most coral reefs: Nature Climate Change, v. 3 , p. $165-170$

Gleason, D. F., and Wellington, G. M., 1993, Ultraviolet radiation and coral bleaching: Nature, v. 365 , p. $836-838$

Glynn, P. W., 1996, Coral reef bleaching: facts, hypotheses and implications: Global Change Biology, v. 2, p. 495-509.

Goreau, T. J., and Hayes, R. L., 1994, Coral bleaching and ocean "hot spots": Ambio, v. 23, p. 176-180.

Graham, N. A., Jennings, S., MacNeil, M. A., Mouillot, D., and Wilson, S. K., 2015, Predicting climate-driven regime shifts versus rebound potential in coral reefs: Nature, v. 518, p. 94-97.

Hallock, P., 1999, Symbiont-bearing foraminifera, in Sen Gupta, B. K., (ed.), Modern Foraminifera: Kluwer Academic Publishers, p. 123-139.

Hallock, P., 2000, Symbiont-bearing foraminifera: harbingers of global change?: Micropaleontology, v. 46, p. 95-104.

Hallock, P., 2012, The FoRAM Index revisited: uses, challenges, and limitations: Proceedings, Twelfth International Coral 
Reef Symposium, Cairns, Australia, http://www.icrs2012.com/ proceedings/manuscripts/ICRS2012_15F_2.pdf

Hallock, P., Forward, L. B., and Hansen, H. J., 1986, Influence of environment on the test shape of Amphistegina: Journal of Foraminiferal Research, v. 16, p. 224-231.

Hallock, P., Talge, H. K., Smith, K., and Cockey, E. M., 1993, Bleaching in a reef-dwelling foraminifer, Amphistegina gibbosa, in Richmond, R. H. (ed.), Proceedings, 7th International Coral Reef Symposium: University of Guam Press, UOG Station, Guam, v. 1, p. 44-49, http://www.reefbase.org/resource_center/publication/icrs.aspx.

Hallock, P., Talge, H. K., Cockey, E. M., and Muller, R. G., 1995, A new disease in reef-dwelling foraminifera; implications for coastal sedimentation: Journal of Foraminiferal Research, v. 25, p. 280 286.

Hallock, P., Lidz, B. H., Cockey-Burkhard, E. M., and Donnelly, K. B. 2003, Foraminifera as bioindicators in coral reef assessment and monitoring: The FORAM Index: Environmental Monitoring and Assessment, v. 81, p. 221-238.

Hallock, P., Williams, D. E., Toler, S. K., Fisher, E. M., and Talge, H. K., 2006a, Bleaching in reef-dwelling foraminifers: Implications for reef decline: Proceedings, 10th International Coral Reef Symposium, Okinawa, Japan, p. 729-737: http://www. reefbase.org/resource center/publication/icrs.aspx

Hallock, P., Williams, D. E., Fisher, E. M., and Toler, S. K., 2006b, Bleaching in foraminifera with algal symbionts: implications for reef monitoring and risk assessment: Anuário do Instituto de Geociências, Universidade Federal do Rio de Janeiro, Brasil, v. 29 , p. $108-128$.

Hoegh-Guldberg, O., 1999, Climate change, coral bleaching and the future of the world's coral reefs: Marine and Freshwater Research, v. 50, p. $839-866$.

Hoegh-Guldberg, O., and Smith, G. J., 1989, The effect of sudden changes in temperature, light and salinity on the population density and export of zooxanthellae from the reef corals Stylophora pistillata Esper and Seriatopora hystrix Dana: Journal of Experimental Marine Biology and Ecology, v. 129, p. 279-303.

Hohenegger, J., Yordanova, E., Nakano, Y., and Tatzreiter, F., 1999 , Habitats of larger foraminifera on the upper reef slope of Sesoko Island, Okinawa, Japan: Marine Micropaleontology, v. 36, p. 109168.

Jackson, L. E., Janis C. K., and William, S. F., 2000, Evaluation Guidelines for Ecological Indicators: EPA/620/R-99/005: U.S. Environmental Protection Agency, Office of Research and Development, Research Triangle Park, N.C., 107 p.

Jokiel, P. L., and Coles, S. L., 1990, Response of Hawaiian and other Indo-Pacific reef corals to elevated temperature: Coral Reefs, v. 8, p. 155-162.

Jones, R. J., and Hoegh-Guldberg, O., 1999, Effects of cyanide on coral photosynthesis: implications for identifying the cause of coral bleaching and for assessing the environmental effects of cyanide fishing: Marine Ecology Progress Series, v. 177, p. 83-91.

Kelmo, F., and Attrill, M. J., 2013, Severe impact and subsequent recovery of a coral assemblage following the 1997-8 El Nino event: a 17-year study from Bahia, Brazil: PLoS ONE, v. 8, e65073, doi:10.1371/journal.pone. 0065073

Langer, M. L., Weinmann, A. E., Lötters, S., Bernhard, J. M., and Rödder, D., 2013, Climate-driven range extension of Amphistegina (Protista, Foraminiferida): models of current and predicted future ranges: PLoS ONE, e54443, doi: 10.1371/journal.pone.0054443

Lauvset, S. K., Gruber, N., Landshützer, P., Olsen, A., and Tjiputra, J., 2015, Trends and drivers in surface ocean $\mathrm{pH}$ over the past 3 decades: Biogeosciences, v. 12, p. 1285-1298.

Lee, J. J., and Anderson, O. R., 1991, Symbiosis in foraminifera, in Lee, J. J., and Anderson, O. R. (eds.), Biology of Foraminifera: Academic Press, London, p. 157-220.

Lesser, M., and Farrell, J., 2004, Exposure to solar radiation increases damage to both host tissues and algal symbionts of corals during thermal stress: Coral Reefs, v. 23, p. 367-377.

McClanahan, T. R., 2000, Bleaching damage and recovery potential of Maldivian coral reefs: Marine Pollution Bulletin, v. 40, p. 587-597.

Mendez-Ferrer, N., Hallock, P., and Jones, D. L., 2018. Photochemical efficiencies of diatom symbionts in hospite in Amphistegina gibbosa (Foraminifera) across seasons in the Florida Keys, USA: Journal of Foraminiferal Research, v. 48, p. ?-??.
Miranda, R. J., Cruz, I. C., and Leão, Z. M., 2013, Coral bleaching in the Caramuanas reef (Todos os Santos Bay, Brazil) during the 2010 El Niño event: Latin American Journal of Aquatic Research, v. 41, p. 351-360.

Morri, C., Montefalcone, M., Lasagna, R., Gatti, G., Rovere, A., Parravicini, V., Baldelli, G., Colantoni, P., and Bianchi, C. N., 2015, Through bleaching and tsunami: Coral reef recovery in the Maldives: Marine Pollution Bulletin, v. 98, p. 188-200.

Murray, J. W., 2006, Ecology and Applications of Benthic Foraminifera: Cambridge University Press, Cambridge, $426 \mathrm{p}$.

Naseer, A., and Hatcher, B. G., 2004, Inventory of the Maldives' coral reefs using morphometrics generated from Landsat ETM + imagery: Coral Reefs, v. 23, p. 161-168.

NOAA Coral Reef Watch 2015a, NOAA declares third ever global coral bleaching event. Bleaching intensifies in Hawaii, high ocean temperatures threaten Caribbean corals:http://coralreefwatch. noaa.gov/vs/gauges/maldives.php

NOAA Coral Reef Watch 2015b, Bleaching Event Continues, June 2015 Update: http://coralreefwatch.noaa.gov/satellite/ analyses_guidance/global_bleaching_update_20150602.php.

Pisapia, C., El Kateb, A., Hallock, P., and Spezzaferri, S., 2016, Assessing coral reef health in the North Ari Atoll (Maldives) using the Foram Index: Marine Micropaleontology, v. 133, p. 50-57.

Prazeres, M. de F., Martins, S. E., and Bianchini, A., 2011, Biomarkers response to zinc exposure in the symbiont-bearing foraminifer Amphistegina lessonii (Amphisteginidae, Foraminifera): Journal of Experimental Marine Biology and Ecology, v. 407, p. 116-121.

Prazeres, M. de F., Martins, S. E., and Bianchini, A., 2012, Assessment of water quality in coastal waters of Fernando de Noronha, Brazil: the symbiont-bearing foraminifer Amphistegina lessonii (Amphisteginidae, Foraminifera): Journal of Foraminiferal Research, v. 42, p. $56-65$.

Prazeres, M., Uthicke, S., and Pandolfi, J. M., 2016, Changing light levels induce photo-oxidative stress and alterations in shell density of Amphistegina lobifera (Foraminifera): Marine Ecology Progress Series, v. 549, p. 69-78.

Prazeres, M., Roberts, T. E., and Pandolfi, J. M., 2017, Variation in sensitivity of large benthic Foraminifera to the combined effects of ocean warming and local impacts: Scientific Reports, v. 7, doi: $10.1038 /$ srep45227

Ramamirtham, C. P., 1968, Vertical distribution of temperature, salinity and dissolved oxygen in the Maldives region of the Indian Ocean: Indian Journal of Fisheries, v. 15, 27-39.

Ramirez, A., 2008, Patch Reef Health in Biscayne National Park: A Comparison of Three Foraminiferal Indices: M.S. Thesis, University of South Florida, Tampa, FL, 137 p.: http:// scholarcommons.usf.edu/etd/465/

Reymond, C. E., Uthicke, S., and Pandolfi, J. M., 2012, Tropical Foraminifera as indicators of water quality and temperature: Proceeding, 12th International Coral Reef Symposium, Cairns, Australia. http://www.reefbase.org/resource_ center/publication/icrs.aspx

Sheppard, C. R. C., Davy, S. K., and Pilling, G. M., 2009, The Biology of Coral Reefs: Oxford University Press, New York, 339 p.

Schmidt, C., Heinz, P., Kucera, M., and Uthicke, S., 2011, Temperatureinduced stress leads to bleaching in larger benthic foraminifera hosting endosymbiotic diatoms: Limnology and Oceanography, v. 56, p. $1587-1602$

Schmidt, C., Morard, R Prazeres, M. Barak, H, and Kucera, M., 2016a, Retention of high thermal tolerance in the invasive foraminifera Amphistegina lobifera from the Eastern Mediterranean and the Gulf of Aqaba: Marine Biology, v. 163, doi: 10.1007/s00227-016-2998-4

Schmidt, C., Titelboim, D., Brandt, J., Herut, B., Abramovich, S., Almogi-Labin, A., and Kucera, M., 2016b, Extremely heat tolerant photo-symbiosis in a shallow marine benthic foraminifera: Scientific Reports, v. 6, doi: 10.1038/srep30930

Sinutok, S., Hill, R., Doblin, M. A., Wuhrer, R., and Ralph, P. J., 2011, Warmer more acidic conditions cause decreased productivity and calcification in subtropical coral reef sediment-dwelling calcifiers: Limnology and Oceanography, v. 56, p. 1200-1212.

Strong, A. E., Goreau, T. J., and Hayes, R. L., 1998, Ocean hot spots and coral reef bleaching: January-July 1998: Reef Encounters, v. 24 , p. $20-22$. 
Stuhr, M., Reymond, C. E, Rieder, V., Hallock, P., Rahnenfuhrer, J., Westphal, H., Kucera, M., 2017, Reef calcifiers are adapted to episodic heat stress but vulnerable to sustained warming. Plos One, 20 p.: doi.org/10.1371/journal.pone. 0179753

Talge, H. K., and Hallock, P., 1995, Cytological examination of symbiont loss in a benthic foraminifera, Amphistegina gibbosa: Marine Micropaleontology, v. 26, p. 107-113.

Talge, H. K., and Hallock, P., 2003, Ultrastructural responses in fieldbleached and experimentally stressed Amphistegina gibbosa (Class Foraminifera): Journal of Eukaryotic Microbiology, v. 50, p. 324 333.

Uthicke, S., Vogel, N., Doyle, J., Schmidt, C., and Humphrey, C., 2012 , Interactive effects of climate change and eutrophication on the dinoflagellate-bearing benthic foraminifer Marginopora vertebralis: Coral Reefs, v. 31, p. 401-414.

Wild, C., Niggl, W., Naumann, M. S., and Haas, A. F., 2010, Organic matter release by Red Sea coral reef organisms - potential effects on microbial activity and in situ $\mathrm{O}_{2}$ availability: Marine Ecology Progress Series, v. 411, p. 61-71.

Wilkinson, C. R., 1999, Global and local threats to coral reef functioning and existence: review and predictions: Marine and Freshwater Research, v. 50, p. 867-878.

Wilkinson, C. R., Lindén O., Cesar, H., Hodgson, G., Rubens, J., and Strong, A. E., 1999, Ecological and socioeconomic impacts of 1998 coral mortality in the Indian Ocean: An ENSO impact and a warning of future change?: Ambio, v. 28, p. 188-196.

Williams, D. E., 2002, Population ecology of bleaching-stressed Amphistegina gibbosa in the Florida Keys (1991-1999): influence of solar radiation on reef-dwelling foraminifera: Ph.D. Dissertation, University of South Florida, Tampa, FL, 164 p.: http:// scholarcommons.usf.edu

Williams, D. E., Hallock, P., Talge, H. K., Harney, J. N., and McRae, G., 1997, Responses of Amphistegina gibbosa populations in the Florida Keys (USA) to a multi-year stress event (1991-1996): Journal of Foraminiferal Research, v. 27, p. 264-269.

Yates, K. K., Dufore, C., Smiley, N., Jackson, C., and Halley, R. B. 2007, Diurnal variation of oxygen and carbonate system parameters in Tampa Bay and Florida Bay: Marine Chemistry, v. 104, p. 110 124.

Zweng, M. M., Reagan, J. R., Antonov, J. I., Locarnini, R. A., Mishonov, A.V., Boyer, T. P., Garcia, H. E., Baranova, O. K, Johnson, D. R., Seidov, D., and Biddle, M. M., 2013, World Ocean Atlas 2013, Volume 2: Salinity, in Levitus, S. and Mishonov, A. (eds.), NOAA Atlas NESDIS 74: $39 \mathrm{p}$.

Received 23 May 2017 Accepted 1 August 2017 